\title{
Meningkatkan Prestasi Belajar IPS Materi Mengenal Cara Menghadapi Bencana Alam Dengan Model Cooperative Tipe Circuit Learning Siswa Kelas VI Semester I SDN Batu Kembar Kecamatan Janapria Tahun Pelajaran 2015/2016
}

\author{
Bq Aeniah \\ SDN Batu Kembar Kecamatan Janapria Kabupaten Lombok Tengah
}

\begin{abstract}
Abstrak :Untuk membangkitkan semangat belajar maka dalam pelajaran IPS harus memilih metode yang tepat. Metode yang di pilih dalam pembelajaran harus metode dengan pendekatan yang berpusat pada siswa sehingga siswa merasa lebih terdorong untuk turut aktif dalam pembelajaran. Pendekatan Cooperative Circuit Learning merupakan pendekatan dengan konsep dasar yang mewadahi, menginspirasi, menguatkan, dan melatari pemikiran tentang bagaimana metode pembelajaran diterapkan berdasarkan teori tertentu. Pada materi Cooperative Circuit Learning yang di ajarkan di Kelas VI Sekolah Dasar Negeri Batu Kembar Kecamatan Janapria pendekatan Cooperative Circuit Learning di rasa tepat sehingga akan di gunakan dalam penelitian ini sebagai cara untuk meningkatkan prestasi belajar siswa pada materi Pentingnya Koperasi dalam meningkatkan kesejahteraan . Permasalahan yang di angkat dalam PTK ini adalah Meningkatkan Semangat Belajar Siswa Dalam Pembelajaran Pentingnya Koperasi dalam meningkatkan kesejahteraan Melalui Pendekatan Cooperative Circuit Learning di Kelas VI Sekolah Dasar Negeri Batu KembarKecamatan Janapria Tahun Ajaran 2016/2017. Hasil akhir dari penelitian ini adalah Dengan Pendekatan Cooperative Circuit Learning yang telah dilaksanakan maka terdapat peningkatan Semangat Belajar Siswa Dalam Pembelajaran Pentingnya Koperasi dalam meningkatkan kesejahteraan pada siswa Kelas VI Sekolah Dasar Negeri Batu KembarKecamatan Janapria . Terbukti dari data hasil belajar pada siklus 1 nilai rata rata yang siswa mencapai 72,1 Dan hasil rata rata nilai siswa yang pada siklus 2 ini mencapai 77,5. Dapat di simpulkan bahwa penggunaan Pendekatan Cooperative Circuit Learning dalam meningkatkan Prestasi Belajar Siswa Dalam Pembelajaran IPS materi Pentingnya Koperasi dalam meningkatkan kesejahteraan .
\end{abstract}

Kata Kunci : Prestasi Belajar "Mengenal cara menghadapi Bencana Alam, Pendekatan Cooperative Circuit Learning

\section{PENDAHULUAN}

Peranan pendidikan sangat penting untuk mempersiapkan anak didik untuk berpartisipasi secara utuh dalam kehidupan bermasyarakat dan berbangsa. Pendidikan merupakan pondasi utama suatu bangsa untuk maju sehingga kita perlu mempersiapkannya dengan baik. Pada saat ini, kita perlu melihat kembali praktik-praktik pembelajaran yang ada di sekolah-sekolah. Banyak orang beranggapan bahwa pembelajaran di sekolah yaitu guru mengajar dan menyodorkan informasi dan pengetahuan kepada siswa. Lebih parah lagi, siswa di tuntut untuk memperoleh nilai-nilai yang tinggi. Paradigma lama beranggapan bahwa pembelajaran adalah guru memberikan pengetahuan kepada siswa yang pasif.
Banyak guru menganggap paradigma lama ini sebagai satu-satunya alternatif. Mereka mengajar dengan metode ceramah dan mengharapkan siswa Duduk, Diam, Catat, dan Hafal (3DCH) serta mengadu siswa satu sama lain (Lie, 2007:3).

Dalam implikasinya pada dunia belajar, siswa atau pelajar tidak akan terprestasi secara penuh dalam belajar. Termasuk dalam mata pelajaran IPS yang di rasa membosankan. Guru sebagai seorang pendidik harus tahu apa yang diinginkan oleh para siswanya. Seperti kebutuhan untuk berprestasi, karena setiap siswa memiliki kebutuhan untuk berprestasi yang berbeda satu sama lainnya. Tidak sedikit siswa yang memiliki semangat belajar yang rendah, 
mereka cenderung takut gagal dan tidak mau menanggung resiko dalam mencapai prestasi belajar yang tinggi. Meskipun banyak juga siswa yang memiliki semangat belajar yang tinggi. Siswa memiliki semangat belajar tinggi kalau keinginan untuk sukses benarbenar berasal dari dalam diri sendiri. Siswa akan bekerja keras baik dalam diri sendiri maupun dalam bersaing dengan siswa lain. Untuk membangkitkan semangat tersebut, maka dalam pelajaran IPS harus memilih metode yang tepat. Metode yang di pilih dalam pembelajaran harus metode dengan pendekatan yang berpusat pada siswa sehingga siswa merasa lebih terdorong untuk turut aktif dalam pembelajaran.

\section{Rumusan Masalah}

Dari latar belakang masalah yang di sebutkan di atas, maka rumusan masalah dalam penelitian ini adalah "Bagaimanakah Meningkatkatkan Prestasi Belajar IPS Materi Mengenal Cara Menghadapai Bencana Alam Dengan Model Cooperative Circuit Learning Siswa Kelas VI Semester I SDN Batu Kembar Kecamatan Janapria Tahun pelajaran 2015/2016"

\section{Tujuan Penelitian}

Sesuai dengan rumusan maslaah yang ada, penelitian ini bertujuan untuk mengetahui peningkatan Prestasi belajar siswa dalam pembelajaran IPS Materi Mengenal Cara Menghadapai Bencana Alam melalui pendekatan Kooperatif tipe Circuit Learning Kelas VI Semester I SDN Batu Kembar Kecamatan Janapria Tahun Pelajaran 2015/2016

\section{Manfaat Penelitian}

Manfaat dari penelitian ini adalah Memberikan bekal kecakapan berfikir ilmiah melalui keterlibatan siswa dalam kegiatan penelitian tindakan kelas yang dilakukan oleh guru serta,memugkinkan guru secara aktif mengembangkan pengetahuan dan keterampilannya

\section{LANDASAN TEORI DAN KAJIAN PUSTAKA \\ Pengertian Belajar}

Setiap orang menjadi dewasa karena belajar dan pengalaman selama hidupnya. Belajar pada umumnya dilakukan seseorang sejak mereka ada di dunia ini. Ada beberapa ahli yang mendefinisikan istilah belajar dengan beberapa uraian yang tidak sama. Untuk dapat memahami dan mempunyai gambaran yang luas, berikut ini diberikan beberapa pengertian belajar menurut beberapa ahli :

a. Whittaker, belajar adalah proses tingkah laku yang ditimbulkan atau diubah melalui latihan atau pengalaman.

b. Kimble, belajar adalah perubahan relatif permanen dalam potensi bertindak, yang berlangsung sebagai akibat adanya latihan yang diperkuat.

c. Winkel, belajar adalah aktivitas mental atau psikis, yang berlangsung dalam interaksi aktif dengan lingkungan yang menghasilkan perubahan-perubahan dalam pengetahuan, pemahaman, ketrampilan, nilai dan sikap.

d. Sdaffer, belajar merupakan perubahan tingkah laku yang relatif menetap, sebagai hasil pengalaman-pengalaman atau praktik.

Berdasarkan definisi di atas dapat dikatakan bahwa, belajar adalah suatu proses usaha yang dilakukan individu untuk memperoleh perubahan tingkah laku yang baru sebagai pengalaman individu itu sendiri.

Perubahan yang terjadi setelah seseorang melakukan kegiatan belajar dapat berupa ketrampilan, sikap, pengertian ataupun pengetahuan. Belajar merupakan peristiwa yang terjadi secara sadar dan disengaja, artinya seseorang yang terlibat dalam peristiwa belajar pada akhirnya menyadari bahwa ia mempelajari sesuatu, sehingga terjadi perubahan pada dirinya sebagai akibat dari kegiatan yang disadari dan sengaja dilakukannya tersebut.

\section{Pengertian Prestasi Belajar}

Prestasi berasal dari bahasa Belanda, yang berarti hasil bisnis. Prestasi yang diperoleh dari upaya yang telah dilakukan. Memahami pencapaian tersebut, rasa prestasi diri adalah hasil dari bisnis seseorang. Prestasi dapat dicapai dengan mengandalkan kemampuan intelektual, emosional, dan spiritual, serta ketahanan dalam menghadapi semua aspek situasi kehidupan.

Sebuah karakter pemain yang mencintai pekerjaan, inisiatif dan kreatif, 
pantang menyerah, serta menjalankan tugas dengan sungguh-sungguh karakter ini menunjukkan bahwa untuk pencapaian tertentu, dibutuhkan kerja keras.

- Sumadi Suryabrata, Prestasi adalah sebagai rumus yang diberikan guru mata pelajaran mengenai kemajuan atau prestasi belajar selama periode tertentu. (Sumadi Suryabrata, 1998)

- Siti Pratini Prestasi Belajar adalah hasil dari seseorang dalam kegiatan pembelajaran. (Siti Pratini, 2005)

- Kamus Bahasa Indonesia yang dinamakan Prestasi adalah hasil yang telah dicapai, dilakukan, dilakukan dan sebagainya.

- Bukhari M.Ed, Prestasi bisa kita artikan sebagai hasil yang dicapai atau hasil yang telah dicapai. (Bukhari M, 1983)

- WS. Winkel, Prestasi belajar adalah hasil dari pembelajaran yang ditampilkan oleh siswa berdasarkan kemampuan internal yang diperoleh sesuai dengan tujuan instruksional. (WS Winkel, 1989)

\section{Macam-Macam Prestasi}

Ada beberapa prestasi yang dapat dicapai oleh setiap orang, diantaranya:

- Prestasi Belajar

Hasil yang diperoleh untuk usaha untuk belajar. Prestasi siswa misalnya di sekolah, menjadi juara umum setiap tahun.

- Prestasi Kerja

Adalah hasil yang diperoleh dari usaha kerja yang telah dilakukan. Misalnya promosi kerja keras mereka selama bertahun-tahun. Contoh penghargaan untuk pencapaian artistik

- Prestasi Seni

Adalah hasil yang diperoleh dari bisnis seni. Misalnya, pencapaian penyanyi atau bentuk lain dari seniman upeti.

- Prestasi Olah raga

Hasil yang diperoleh untuk usaha dan kerja keras di bidang olahraga. Sebagai contoh, seorang atlet mendapat medali emas di tempat pertama diraih saat menghadiri Pekan Olahraga Nasional (PON).

- Prestasi Lingkungan Hidup
Kinerja lingkungan adalah sebuah prestasi yang diperoleh oleh upaya untuk menyelamatkan lingkungan. Misalnya individu atau kelompok mendapatkan penghargaan untuk upaya konservasi lingkungan seperti penanaman pohon atau penghijauan.

\section{Arti Penting Prestasi}

Prestasi dapat digunakan untuk meningkatkan potensi kita. Berikut ini adalah prestasi penting:

1. Prestasi adalah wujud nyata dari kualitas dan kuantitas yang diperoleh oleh seseorang di bisnis yang diperoleh.

2. Prestasi adalah sebuah pengalaman yang orang mengalami dan bisa menjadi pelajaran berharga untuk masa depan.

3. Prestasi adalah kebanggaan bagi diri sendiri, keluarga, kelompok, masyarakat, bangsa dan negara.

4. Prestasi digunakan untuk mengukur tingkat pengetahuan, kecerdasan, dan keterampilan seseorang, kelompok, masyarakat, bangsa dan negara.

Pengertian dan Langkah-langkah Model Pembelajaran Kooperatif tipe Circuit Learning

Perkembangan ilmu pengetahuan dan teknologi yang semakin pesat berdampak pula pada kemajuan model pembelajaran yang digunakan untuk mengembangkan kualitas guru dan peserta didik. Salah satu model pembelajaran yang berkembang saat ini adalah model pembelajaran kooperatif atau disebut juga dengan cooperative learning. Menurut Fathurrohman (2015:44) "pembelajaran kooperatif merupakan model pembelajaran yang mengutamakan kerja sama di antara siswa untuk mencapai tujuan pembelajaran".

Sedangkan menurut Artzt dan Newman dalam Al-Tabany (2014:108) menyatakan: Bahwa dalam belajar kooperatif siswa belajar bersama sebagai suatu tim dalam menyelesaikan tugas kelompok untuk mencapai tujuan bersama. Jadi setiap anggota kelompok memiliki tanggung jawab yang sama untuk keberhasilan kelompoknya. Berdasarkan pendapat beberapa ahli di atas dapat ditarik kesimpulan bahwa pembelajaran kooperatif adalah model 
pembelajaran yang mengutamakan kerja sama dalam suatu tim untuk mencapai tujuan pembelajaran dan setiap anggota kelompok memiliki tanggung jawab yang sama untuk mencapai keberhasilan kelompoknya. Menurut Fathurrohman (2015:48-49) tujuan cooperative learning, yaitu:Hasil belajar akademik

Menurut Huda dalam Fathurrohman (2015:48) Beberapa penelitian dari tokoh cooperative learning seperti Jhonson dan Jhonson, Slavin, Kagan dan sebagainya membuktikan bahwa model ini lebih unggul dalam membantu peserta didik memahami konsep-konsep yang sulit dan dapat meningkatkan nilai peserta didik pada belajar akademik.

\section{Penerimaan terhadap perbedaan individu}

Menurut Ibrahim dkk dalam Fathurrohman (2015:48) tujuan lain model pembelajaran kooperatif (cooperatif learning) adalah cooperative learning memberikan peluang bagi peserta didik dari berbagai latar belakang dan kondisi yang berbeda untuk bekerja dengan saling bergantung pada tugas akademik dan melalui penghargaan kooperatif siswa akan belajar menghargai satu sama lain.

Menurut Spencer Kagan dan Miguel Kagan dalam Fathurrohman (2015:49) tujuan ketiga adalah mengajarkan kepada siswa keterampilan bekerja sama dan kolaborasi. Keterampilan-keterampilan sosial penting dimiliki oleh siswa sebagai bekal untuk hidup dalam lingkungan sosialnya.

Pembelajaran kooperatif tidak sama dengan sekedar belajar dalam kelompok. Ada unsur-unsur dasar pembelajaran kooperatif yang membedakannya dengan pembagian kelompok yang dilakukan asal-asalan. Menurut Roger dan Johnson dalam Suprijono (2014:58) yaitu: Tidak semua belajar kelompok bisa dianggap pembelajaran kooperatif. Untuk mencapai hasil yang maksimal, lima unsur dalam model pembelajaran kooperatif harus diterapkan. Lima unsur tersebut adalah: (1) Positive Interpendence (saling ketergantungan positif), (2) Personal responsibility (tanggung jawab perseorangan), (3) Face to face promotive interaction (interaksi promotif),
(4) Interpersonal skill (komunikasi antaranggota), (5) Group processing (pemrosesan kelompok).

Pengertian dan Langkah-Langkah Model Pembelajaran Kooperatif Tebak Kata Salah satu tipe model pembelajaran kooperatif yang ada saat ini adalah circuit learning. Menurut DePorter dkk (2010:230) pengertian circuit learning adalah "belajar memutar, disebut belajar memutar karena siswa benar-benar menempuh informasi dalam pola yang sama setiap hari". Sedangkan menurut Huda (2013:311) circuit learning merupakan "salah satu tipe model pembelajaran kooperatif yang memaksimalkan pemberdayaan pikiran dan perasaan dengan pola penambahan (adding) dan pengulangan (repetition)".

Berdasarkan pendapat beberapa ahli di atas dapat disimpulkan bahwa circuit learning adalah pembelajaran yang memaksimalkan pemberdayaan pikiran dan perasaan dengan pola penambahan (adding) dan pengulangan (repetition) yang diterapkan dengan pola yang sama setiap hari kepada siswa. Pola penambahan (adding) dalam circuit learning adalah guru membuat peta konsep dalam menjelaskan materi pembelajaran kepada siswa, kemudian ketika ingin melanjutkan materi pembelajaran pada pertemuan berikutnya guru menambahkan bagian cabang peta konsep yang baru dari cabang peta konsep yang sudah dipelajari pada pertemuan sebelumnya sesuai dengan materi yang akan dipelajari. Begitu juga dengan lembar kerja siswa yang disediakan oleh guru. Guru membuat lembar kerja siswa dalam bentuk peta konsep yang pada bagian tertentu akan diisi oleh siswa sesuai dengan bahasa mereka sendiri, begitu juga pada proses pembelajaran pada pertemuan selanjutnya guru menambahkan bagian cabang peta konsep yang baru dari cabang peta konsep yang sudah dipelajari sebelumnya untuk diisi siswa sesuai dengan materi pembelajaran yang dipelajari. Begitu juga pada hari berikutnya sampai pokok bahasan tersebut selesai. Sedangkan pengulangan (repetition) adalah guru mengulang kembali sekilas tentang pelajaran yang telah dipelajari pada pertemuan 
sebelumnya pada waktu akan melanjutkan materi pembelajaran berikutnya dan begitu juga pada pertemuan berikutnya sampai pokok bahasan tersebut selesai diajarkan.

Circuit learning dimulai dengan kegiatan afirmasi pada awal pembelajaran dan kegiatan visualisasi dalam menjelaskan materi pembelajaran. Menurut DePorter dkk (2010:60) afirmasi adalah "penguatan atau penegasan". Kegiatan afirmasi digunakan untuk mengkondisikan siswa dengan keadaan pikiran yang sukses dan percaya diri. Siswa cenderung mempunyai asosiasi negatif dengan ujian, ulangan, atau saat mengikuti materi pembelajaran yang dianggap sulit. Karena mengalami keadaan yang demikian siswa merasa takut, dan rasa takut membuat siswa tertutup. Bahkan setelah berjam-jam belajar banyak siswa memiliki pikiran kosong atau tidak dapat menerima meteri pembelajaran dengan baik.

\section{Materi Pelajaran IPA}

\section{Bencana Alam dan cara menhadapinya}

Bencana alam adalah suatu

kejadian atau kerusakan yang disebabkan oleh alam dan biasanya datangnya secara tiba-tiba atau mendadak, dan kemungkinan besar akan menimbulkan kerugian materi bahkan sampai jiwa manusia. Macam-macam bencana alam adalah sebagai berikut:

\section{Gunung Meletus}

Gunung meletus terjadi sebagai akibat endapan magma di dalam perut bumi yang didorong keluar oleh gas yang bertekanan tinggi. Letusan itu membawa abu dan batu yang disemburkan dengan keras hingga bisa mencapai radius lebih dari $18 \mathrm{~km}$ atau lebih. Sedangkan lavanya membanjiri daerah hingga radius 90 kilometer. Selain mengeluarkan abu, batu-batuan dan lava, letusan gunung juga mengeluarkan gas yang sangat berbahaya dan mematikan atau yang biasa kita sebut wedus gembhel.

Pada beberapa gunung berapi biasanya pemerintah sudah menempatkan pos-pos pengawasan yang bertugas memantau kegiatan gunung berapi tersebut, sehingga akan segera diketahui jika gunung berapi akan meletus.

\section{Banjir}

Banjir adalah peristiwa naiknya air dan menggenangi daratan yang biasanya kering. Banjir bandang adalah mengalirnya air dengan deras melewati daratan yang biasanya kering. Banjir bandang terjadi akibat hujan lokal yang sangat deras.

\section{Angin Puting Beliung/Angin Puyuh}

Angin puting beliung adalah angin kencang yang kejadiannya sangat singkat dengan kecepatan berangsur-angsur melemah. Tapi, angin kencang belum tentu disebut angin puting beliung. Kriteria angin puting beliung adalah biasanya terjadi antara 3-5 menit dengan kecepatan mencapai 40-50 $\mathrm{km} / \mathrm{jam}$. Gerakannya yang berputar semakin cepat menjadikannya sebuah pusaran angin.

Kita perlu mengetahui penyebab dan gejala datangnya angin puting beliung sebagai berikut:

1. Lebih sering terjadi pada siang/sore hari, tapi terkadang malam hari.

2. Sehari sebelumnya udara pada malam hari sampai pagi hari terasa agak panas atau menjadi lebih gerah.

3. Sekitar pukul 10.00 pagi terlihat awan berlapis-lapis (awan cumulus). Di antara awan tersebut trdpt satu jenis awan yg mempunyai batas tepinya sangat jelas, berwarna abu-abu, dan menjulang tinggi seperti bunga kol.

4. Tiba-tiba, awan tersebut akan berubah warna dari tadinya putih keabu-abuan menjadi hitam pekat (awan cumulunimbus).

5. Perhatikan pepohonan di sekitar. Jika ada dahan atau ranting yang bergoyang cepat karena tiupan angin, hal itu pertanda bahwa hujan dan angin kencang akan datang. Terlebih lagi, tiupan angin itu terasa sangat dingin.

6. Biasanya hujan yang pertama kali turun adalah hujan deras secara tiba-tiba. Jika hujannya gerimis, angin kencang akan terjadi jauh dari lokasi kita.

7. Terdengar petir bersahutan yang sangat keras. Jika ada pertanda tersebut maka kemungkinan besar akan terjadi hujan lebat, disertai petir dan angin kencang.

8. Perlu diwaspadai jika 1 atau 3 hari berturut turut tidak turun hujan pada musim hujan. 
Jika terjadi demikian maka kemungkinan besar hujan sangat deras yang pertama kali turun diikuti angin kencang, termasuk angin puting beliung.

\section{Tanah Longsor}

Tanah longsor adalah runtuhnya tanah, bebatuan, atau lumpur dalam jumlah besar secara tiba-tiba atau berangsur. Kecepatan longsoran bisa mencapai 18 hingga 35 kilometer perjam. Secara umum, daerah yang rawan terjadi tanah longsor yaitu daerah yang pernah terjadi tanah longsor, daerah yang memiliki topografi terjal dan gundul, daerah aliran air hujan, dan daerah dengan tekstur tanah sangat gembur.

\section{METODE PENELITIAN}

Adapun rancangan yang digunakan dalam penelitian ini adalah menggunakan Penelitian Tindakan Kelas (Classromm Activity Research). Pelaksanaan tindakan dalam PTK meliputi empat alur (langkah): (1) perencanaan tindakan; (2) pelaksanaan tindakan; (3) Pengamatan; (4) refleksi.

Alur (langkah) pelaksanaan tindakan yang dimaksud dapat dilihat pada gambar berikut. Sebelum melaksanakan tindakan, terlebih dahulu peneliti merencanakan secara seksama jenis tindakan yang akan dilakukan. Kedua, setelah rencana disusun secara matang, barulah tindakan itu dilakukan. Ketiga, bersamaan dengan dilaksanakan tindakan, peneliti mengamati proses pelaksanaan tindakan itu sendiri dan akibat yang ditimbulkannya. Keempat, berdasarkan hasil pengamatan tersebut, peneliti kemudian melakukan refleksi atas tindakan yang telah dilakukan. Jika hasil refleksi menunjukkan perlunya dilakukan perbaikan atas tindakan yang telah dilakukan., maka rencana tindakan perlu disempurnakan lagi agar tindakan yang dilaksanakan berikutnya tidak sekedar mengulang apa yang telah diperbuat sebelumnya. Demikian seterusnya sampai masalah yang diteliti dapat mengalami kemajuan.

Adapun rancangan penelitian tindakan kelas ini dilakukan dalam II siklus. Dengan catatan: Apabila siklus I berhasil sesuai kriteria yang diinginkan, maka tetap dilakukan siklus II untuk pemantapan, tetapi kalau siklus I tidak berhasil, maka dilakukan siklus II dengan cara menyederhanakan materi dan menambah media pembelajaran. Apabila pada siklus II belum terjadi peningkatan, maka siklus III harus dipersiapkan untuk mengatasi kesulitan yang dialami siswa.

\section{HASIL PENELITIAN DAN PEMBAHASAN \\ Siklus 1}

Pada siklus ke I adalah meskipun masih terdapat beberapa kesulitan yang dihadapi oleh siswa dalam pembelajaran Pentingnya Koperasi dalam meningkatkan kesejahteraan , akan tetapi penerapan pendekatan Cooperative Circuit Learning pada siklus I ini berjalan dengan cukup baik. Hal ini terlihat pada data hasil belajar Siswa dalam Mengikuti Pelajaran IPS Materi Mengenal Cara Menghadapai Bencana Alam pada siklus 1 yang rata-rata siswa sudah mencapai nilai KKM dan menunjukan adanya peningkatan nilai hasil belajar dari pra siklus.

\section{Siklus 2}

Penerapan pendekatan Cooperative Circuit Learning banyak menuntut peran aktif siswa karena pendekatan ini adalah pendekatan pembelajaran yang berorientasi pada siswa. Hal ini dibuktikan dengan perolehan hasil belajar siswa yang mengalami peningkatan dimulai dari pelaksanaan pra siklus sampai pada siklus II. Hasil perolehan nilai siswa menunjukan adanya peningkatan nilai hasil belajar dari siklus-siklus sebelumnya. Dapat di simpulkan bahwa ada peningkatan hasil belajar siswa dari pra siklus hingga siklus II. Terbukti bahwa jumlah siswa yang tuntas mengalami peningkatan, dan jumlah siswa yang belum tuntas mengalami penurunan.

Pada proses pelaksanaan siklus ke-1 siswa diminta untuk mempelajari Pentingnya Koperasi dalam meningkatkan kesejahteraan dalam IPS melalui pendekatan Cooperative Circuit Learning . Dengan pendekatan Cooperative Circuit Learning yang berpusat pada siswa maka siswa lebih tertarik dan bersemangat dalam melaksanakan proses pembelajaran. Dengan 
pendekatan pembelajaran yang telah dilaksanakan maka terdapat peningkatan Semangat Siswa Mengikuti Pelajaran Mengenal Cara Menghadapai Bencana Alam - Terbukti pula dari data hasil belajar pada siklus 1 nilai rata rata yang siswa mencapai 72,1 . Hasil observasi pada siklus 1 ini meskipun masih ada beberapa siswa yang tidak semnagat dalam pembelajaran. Tetapi pembelajaran pada siklus 1 ini berjalan lancar. Hal tersebut menunjukan adanya peningkatan Semangat Siswa Mengikuti Pelajaran Pentingnya Koperasi dalam meningkatkan kesejahteraan di bandingkan dengan pra siklus.

Siklus 2

Pada siklus ke II ini terdiri dari kegiatan perencanaan, pengamatan, dan refleksi tindakan.Pada siklus ini pelaksanaan pembelajaran dengan pendekatan Cooperative Circuit Learning juga sama seperti yang di terapkan pada siklus I, dan hasil dari metode penelitian yang sudah di laksanakan menunjukkan peningkatan Semangat Siswa Mengikuti Pelajaran Mengenal Cara Menghadapai Bencana Alam. Hal tersebut dapat di lihat dari hasil rata rata nilai siswa yang pada siklus 2 ini mencapai 77,5. Dan pada hasil observasi sudah banyak siswa yang melakukan aktifitas dan kegiatan yang menunjukkan adanya semangat belajar dalam pembelajaran.

\section{SIMPULAN DAN SARAN}

1. Pada siklus 1 setelah menggunakan pendekatan Cooperative Circuit Learning dalam pembelajaran maka terlihat adanya semangat siswa dalam mengikuti pelajaran Mengenal Cara Menghadapai Bencana Alam.

2. Pada siklus 1 setelah menggunakan pendekatan Cooperative Circuit Learning dalam pembelajaran maka terlihat peningkatan hasil belajar siswa dengan rata rata nilai siswa pada siklus 1 adalah 72,1. Lebih besar dari pra siklus yang memperoleh rata rata hanya 66.3.

3. Pada siklus 2 setelah menggunakan pendekatan Cooperative Circuit Learning dalam pembelajaran maka terlihat adanya peningkatan semangat siswa dalam mengikuti pelajaran Mengenal Cara Menghadapai Bencana Alam.

4. Pada siklus 2 setelah menggunakan pendekatan Cooperative Circuit Learning dalam pembelajaran maka terlihat peningkatan hasil belajar siswa dengan rata rata nilai siswa pada siklus 2 adalah 77,5. Lebih besar dari pra siklus yang memperoleh rata rata hanya 66.3, dan lebih besar dari siklus 1 yang memperoleh rata rata 72,1 .

5. Dapat di simpulkan bahwa penggunaan pendekatan Cooperative Circuit Learning dalam meningkatkan semangat siswa mengikuti pelajaran Mengenal Cara Menghadapai Bencana Alam di Kelas VI Sekolah Dasar Negeri Batu Kembar Kecamatan Janapria Tahun Ajaran 2015 /2016 tepat sasaran.

\section{DAFTAR PUSTAKA}

Ahmadi, Abu dan Widodo Supriyono. 1991. Psikologi Belajar. Jakarta: Rineka Cipta.

Ahmad Rohani. (1997). Media Instruksional Edukatif. Jakarta: Rineka Cipta

Arief S. Sadiman, dkk. (2006). Media Pendidikan, Pengertian, Pengembangan, dan Pemanfaatannya. Jakarta: Pustekkom. Dikbud. dan PT. Raja Grafindo Persada

Darmansyah. 2006. Penelitian Tindakan Kelas. UNP

Depdiknas. 2004. Pedoman Penulisan Karya Ilmiah. Cetakan Eisi ke empat Malang Pers.

Goleman, Daniel, Emitional Intelligence Kecerdasan Emosional Mengapa EQ Lebih Penting Daripada IQ, Jakata: PT Gramedia Pustaka Utama, 2004.

Hamalik, Oemar. 2002. Proses Belajar Mengajar. Jakarta: Bumi Asara.

Ivor. K.Davies. 1991. Pengelolaan Belajar. Jakarta CV Rajawali

Nana Sujana. 1989. Teori-teori belajar Untuk pengajaran. Bandung

Ngalim Purwanto, Psikologi Pendidikan, Bandung: PT. Remaja Rosdakarya, 2002 
RosdaSardiman. 2006. Interaksi dan Prestasi Belajar Mengajar. Jakarta:

Raja Grafindo Persada

Sugandi, Achmad. 2004. Teori Pembelajaran. Semarang: IKIP Semarang Press.

Slameto. 1995. Belajar Dan Faktor-Faktor Yang Mempengaruhi. Jakarta: Rineka Cipta. Sudjana, Nana. 2001. Penilaian Hasil Proses Belajar Mengajar. Bandung: Remaja Rosdakarya.

Syah, Muhibbin. 2006. Psikologi Belajar. Jakarta: PT Raja Grafindo Persada.

Tabrani Rusyan, Pendekatan dalam Proses Belajar Mengajar, Bandung: PT. Remaja Rosdakarya, 2001.

Tim Penyusun KBBI. 2007. Kamus Besar Bahasa Indonesia (edisi ketiga). Jakarta: Balai Pustaka.

Tim Penyusun Kamus Pembinaan dan Pengembangan Bahasa. (2005). Kamus Besar Bahasa Indonesia. Jakarta: Balai Pustaka

Wina Sanjaya. 2006. Strategi Pembelajaran. Jakarta. Kencana Wiradikromo Sartono. 2003. Dimensi Tiga. Jakarta. Erlangga

Zainal Abidin. 2004. Evaluasi Pengajaran. Padang. UNP 